\title{
THE DISTRIBUTIONAL DATA OF SIMULIIDAE (INSECTA, DIPTERA) SPECIES IN YEŞILILMAK RIVER (TURKEY)
}

\author{
Özge BAŞÖREN * and Nilgün KAZANCI * \\ * Hacettepe University, Beytepe Campus, Science Faculty, Biology Department, Hydrobiology Section, \\ TR-06800, Ankara, Turkey, ozzzge@gmail.com, nilgunkazanci@gmail.com \\ DOI: 10.1515/trser-2015-0046
}

KEYWORDS: Blackflies, habitat degradation, running water, Simuliidae, Turkey, water quality, Yeşilırmak River basin.

\section{ABSTRACT}

This research aims to investigate the Simuliidae fauna of Yeşilırmak River basin and determine the species composition of the collecting sites. The study was carried out in July 2008 and June 2009. One genus and eleven species (Metacnephia sp., Metacnephia subalpina, Simulium (Eusimulium) angustipes, Simulium (Nevermannia) costatum, Simulium (Simulium) argenteostriatum, Simulium (Simulium) bezzii, Simulium (Simulium) ornatum, Simulium (Simulium) trifasciatum, Simulium (Simulium) variegatum, Simulium (Wilhelmia) balcanicum, Simulium (Wilhelmia) lineatum and Simulium (Wilhelmia) pseudequinum) were recorded from 16 collecting sites. The distribution and abundance of Simuliidae species reflect the changes in water quality of Yeşilırmak River, due to agricultural activities and urban areas.

RESUMEN: Datos sobre distribución de Simulidos (Insecta, Diptera) en el Río Yeşilırmak (Turquía).

En este trabajo se determinó la composición específica de la fauna de simúlidos en la cuenca del Río Yeşilırmak en diversos sitios de colecta. El estudio fue llevado a cabo entre junio de 2008 y junio de 2009. En 16 puntos de muestreo se colectaron once especies pertenecientes a un género (Metacnephia sp., Metacnephia subalpina, Simulium (Eusimulium) angustipes, Simulium (Nevermannia) costatum, Simulium (Simulium) argenteostriatum, Simulium (Simulium) bezzii, Simulium (Simulium) ornatum, Simulium (Simulium) trifasciatum, Simulium (Simulium) variegatum, Simulium (Wilhelmia) balcanicum, Simulium (Wilhelmia) lineatum and Simulium (Wilhelmia) pseudequinum). La distribución y abundancia de simúlidos refleja cambios en la calidad del agua en el Río Yeşilırmak, debidos a actividades de agricultura y de áreas urbanas.

REZUMAT: Distribuția simuliidelor (Insecta, Diptera) pe Râul Yeşilırmak (Turcia).

Prezentul studiu are ca scop cercetarea faunei de simuliide din bazinul hidrografic Yeşilırmak și determinarea compoziției la nivel de specie, din stațiile de colectare. Studiul s-a desfăşurat în perioada iulie 2008 - iunie 2009. În cele 16 stații de colectare a fost identificat un gen cu 11 specii (Metacnephia sp., Metacnephia subalpina, Simulium (Eusimulium) angustipes, Simulium (Nevermannia) costatum, Simulium (Simulium) argenteostriatum, Simulium (Simulium) bezzii, Simulium (Simulium) ornatum, Simulium (Simulium) trifasciatum, Simulium (Simulium) variegatum, Simulium (Wilhelmia) balcanicum, Simulium (Wilhelmia) lineatum și Simulium (Wilhelmia) pseudequinum). Distribuția și abundența simuliidelor sunt caracteristice pentru calitatea apei râului Yeşilırmak, influențată de activitățile agricole și de ariile urbane traversate. 


\section{INTRODUCTION}

The species composition of Simuliidae is important when measuring environmental quality of freshwater ecosystems. Specially, filter feeding larvae of blackflies which use dissolved organic matter and plays a key role in nutrient cycle in rivers (Bernotiene, 2006; Zhang et al., 1998).

Several studies demonstrated that the effects of anthropogenic activities have heavily disturbed the aquatic ecosystems in Turkey.

Simuliidae species that respond to various environmental degradations are bioindicators and they are a very useful tool for assessing the quality of running waters. The species composition of Simuliidae can be used as an indicator of agricultural, industrial and urbanization impacts on aquatic ecosystems (Curtean-Bănăduc, 2012; Kazanc1, 2006; Lautenschlager and Kiel, 2005; Feld et al., 2002).

The amount of data that has been gathered, in Turkey, on their relationships with habitat quality, habitat preferences and response to degradations is insufficient. However, there has recently been a significant increase in these studies (Ertunç, 2009; Kalafat, 2008; Kazanc1, 2006; Şirin, 2001; Adler and Şirin, 2014; Başören and Kazanc1, 2012; Başören (Ertunç) and Kazanc1, 2011; Başören (Ertunç) and Kazanc1, 2012; Başören and Kazancı, 2013; ClergueGazeau and Kazanc1, 1992; Crosskey and Zwick, 2007; Kazanc1 and Clergue-Gazeau, 1990; Kazancı and Ertunç, 2008a; Kazancı and Ertunç, 2008b; Kazancı and Ertunç, 2008c; Kazanc1 and Ertunç, 2010; Başören et al., 2013; Ertunç et al., 2008; Şirin et al., 2015).

This research aims to investigate the Simuliidae fauna of Yeşilırmak River basin and to determine the species composition of the collecting sites and the effects of pollution and degradation on Simuliidae fauna.

\section{MATERIAL AND METHODS}

Yeşillrmak River is located in Northern Turkey and it is the third largest basin $(38,730$ $\mathrm{km}^{2}$ ) in Turkey. The catchment covers approximately 5\% of Turkey's total area and its length is $519 \mathrm{~km}$. It runs from Eastern Anatolia and into the Black Sea in Samsun (Fig. 1).

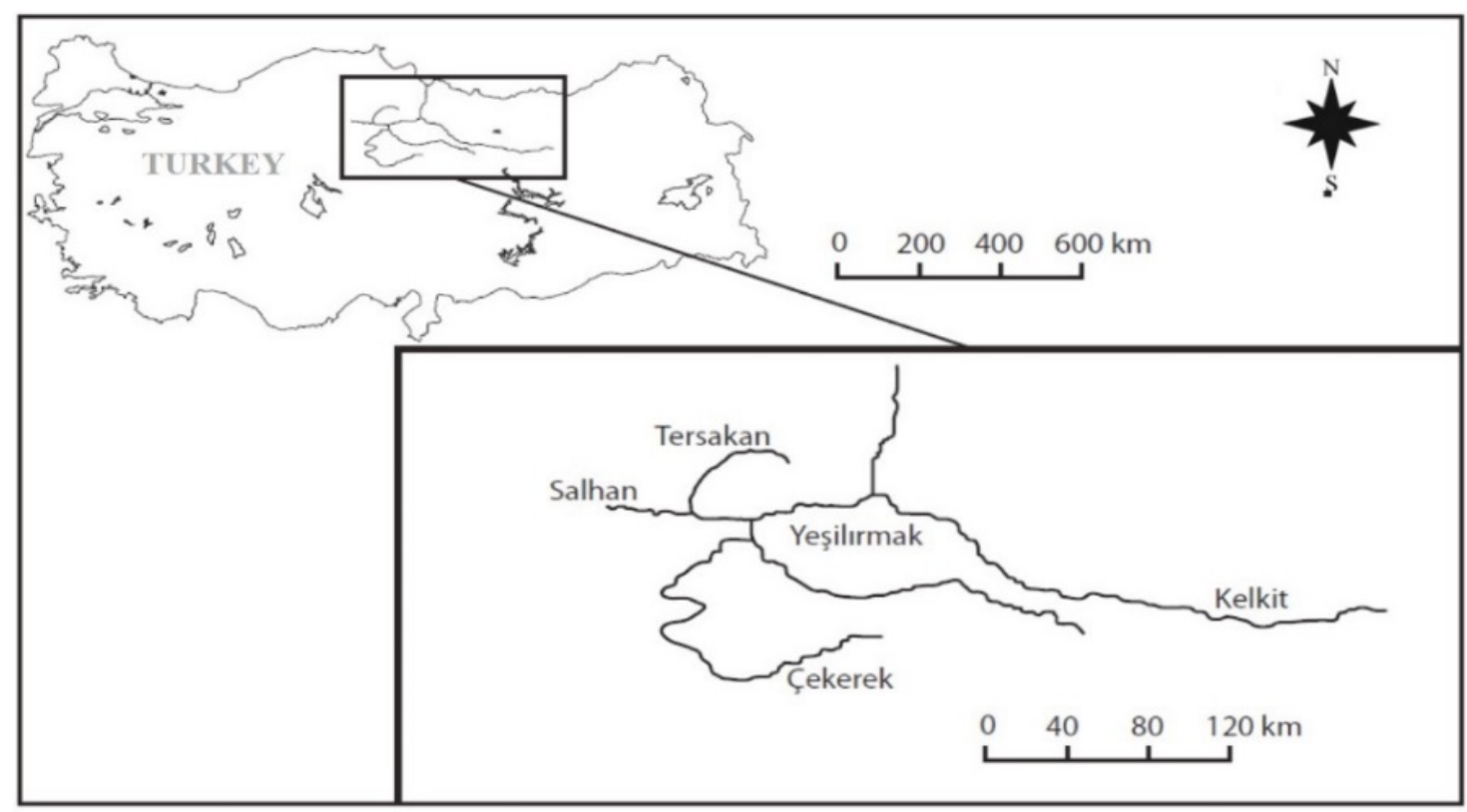

Figure 1: Yeşilırmak River basin. 
The habitat quality of the Yeşilırmak River has been affected by various anthropogenic activities such as urban sewage, physical degradation, agricultural and industrial activities (Figs. 2a, b, c). Hydroelectric power plants, regulators and dams are also serious threats to water and habitat qualities of Yeşilırmak River. All these activities have negative impacts on Simuliidae fauna and this was clearly visible in some of the investigated sites.

Larvae and pupae of Simuliidae were collected by a standard pond net and by hand from different types of habitats at each site. Samples were preserved in $80 \%$ ethyl alcohol (ethanol). The Leica MZ75 stereomicroscope and Olympus CX21FS1 binocular microscope were used for identification. Individuals of Simuliidae were identified according to Rubtsov (1990), Lechthaler and Car (2005), Crosskey and Zwick (2007).

Water temperature, dissolved oxygen and $\mathrm{pH}$ were measured in the field by an YSI 556 multiparameter system. Water samples were also taken from the sites to analyze levels of $\mathrm{PO}_{4}-\mathrm{P}, \mathrm{NO}_{3}-\mathrm{N}, \mathrm{NO}_{2}-\mathrm{N}$ and $\mathrm{NH}_{4}-\mathrm{N}$. These parameters were measured by a Hach DR/890 Datalogging Colorimeter (Tab. 1).

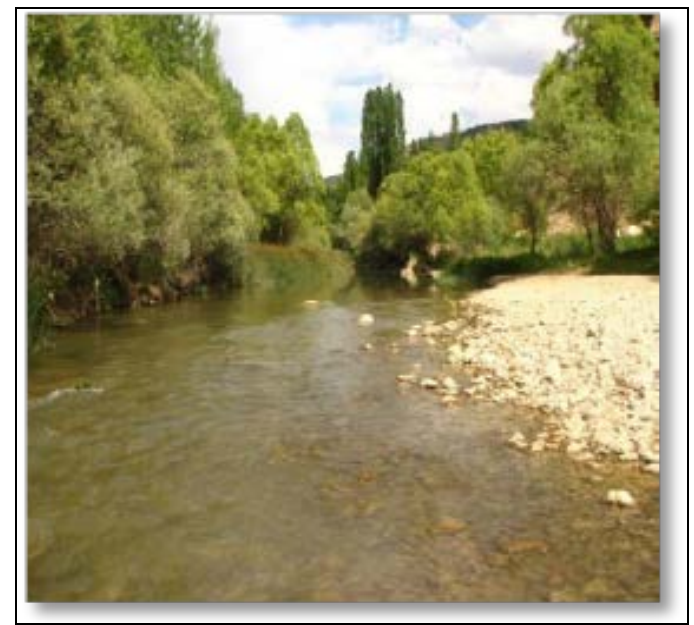

Figure 2a: Some studied sites of Yeşilırmak River.

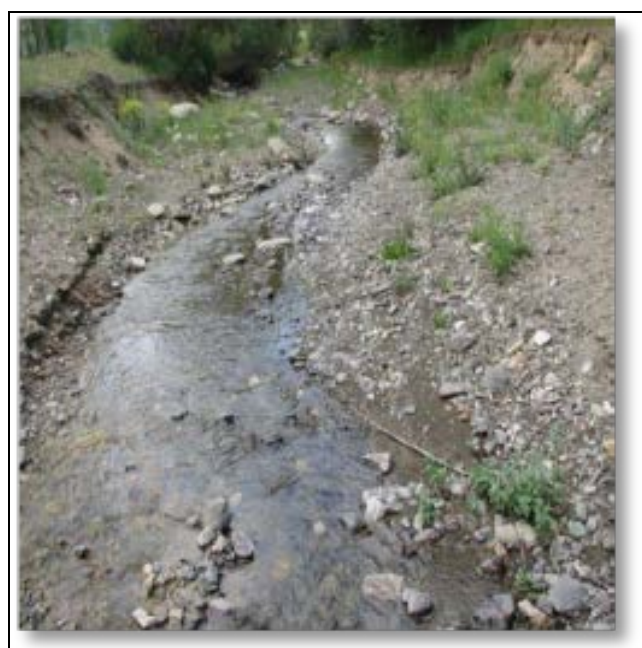

Figure 2b: Some studied sites of Yeşilırmak River. 


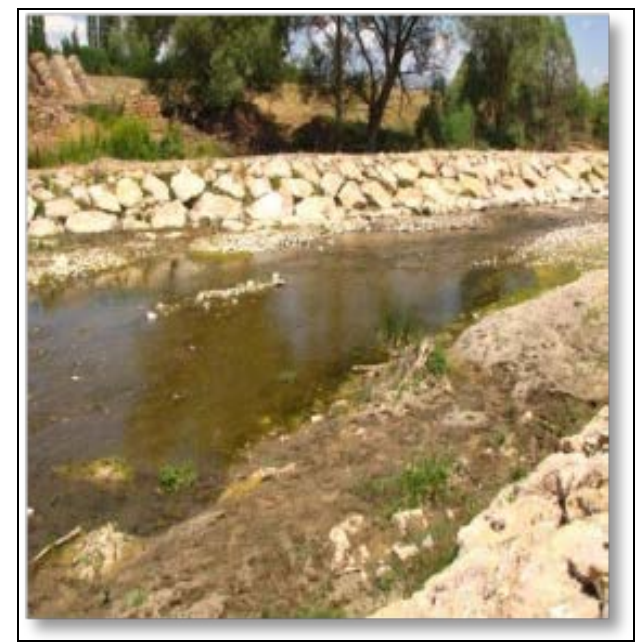

Figure 2c: Some studied sites of Yeşilırmak River.

Klee (1991) and "Regulations of Surface Water Quality Management” prepared by Ministry of Forestry and Water Management (2012) were used to determine the water quality class of the collecting sites.

Blackfly samples were collected from the Yeşilırmak River and tributaries in July 2008 and June 2009. A total of 20 collecting sites (12 sites in 2008, eight sites in 2009) were studied, but Simuliids were found at only 16 sites (10 sites in 2008, six sites in 2009).

\section{RESULTS AND DISCUSSION}

Site 1 (08), 2 (08), 3 (08), 4 (08), and 13 (09) were influenced by agricultural activities and urban pollution. The concentrations of $\mathrm{PO}_{4}-\mathrm{P}$ and $\mathrm{NO}_{2}-\mathrm{N}$ were high in the river due to sewage from urban areas and agricultural runoff. The water qualities of sites 1 (08) and 4 (08) were Class III, site 13 (09) was Class III-IV, site 2 (08) and 3 (08) were Class IV because of two variables $\left(\mathrm{PO}_{4}-\mathrm{P}\right.$ and $\left.\mathrm{NO}_{2}-\mathrm{N}\right)$. Also, all of these sites were physically disturbed. Simuliidae fauna was affected negatively by these deteriorations.

The flow rate of sites 5 (08), 7 (08) and 8 (08) was low because the water level was low due to seasonal conditions. For this reason, the water temperature was high and dissolved oxygen levels were low. Also, agricultural pollution and physical destruction were detected in the stream bed of site 5 (08). The water qualities of these sites were Class III.

The dam is located before site 9 (08), site 10 (08) and site 11 (08). When physicochemical variables were measured and samples were collected, the water was released from the floodgate. The water qualities of these sites were high (Class I and II) because the concentrations of pollutants decreased and values of physicochemical variables were altered. Also, Simuliidae species may have drifted downstream. It is impossible to gather accurate information about the species composition and the water qualities in these sites.

Although there are no agricultural and urban areas around site 14 (09), site 15 (09), site 16 (09), site 17 (09) and site 18 (09), the water qualities of these sites were low (Class III-IV and IV). In these sites, the $\mathrm{PO}_{4}-\mathrm{P}$ concentration was high and $\mathrm{pH}$ value was low because of snow-melt and rainstorms. This situation is observed seasonally and is defined as episodic acidification (Kazanc1, 2009; Wellington and Driscoll, 2004). Simuliidae species as several other aquatic organisms are not able to tolerate acidic waters and they leave their habitat. For this reason, the water quality class and species composition can be misleading in this period. 
Table 1: Physicochemical parameters of the collecting sites.

\begin{tabular}{|c|c|c|c|c|c|c|c|c|}
\hline & $\begin{array}{c}\text { Water } \\
\text { temp. } \\
\left({ }^{\circ} \mathrm{C}\right)\end{array}$ & $\begin{array}{c}\text { Dissolv. } \\
\text { oxygen } \\
(\mathrm{mg} / \mathrm{l})\end{array}$ & $\mathrm{pH}$ & $\mathrm{PO}_{4}-\mathrm{P}$ & $\mathrm{NO}_{3}-\mathrm{N}$ & $\mathrm{NO}_{2}-\mathrm{N}$ & $\mathrm{NH}_{4}-\mathrm{N}$ & $\begin{array}{c}\text { Water } \\
\text { quality } \\
\text { class }\end{array}$ \\
\hline $1(08)$ & 23.32 & 8.15 & 8.15 & 0.222 & 0.294 & 0.030 & 0 & III \\
\hline $2(08)$ & 21.52 & 3.11 & 7.87 & 0.378 & 0 & 0.073 & 0.465 & IV \\
\hline $3(08)$ & 23.34 & 6.71 & 8.23 & 0.391 & 0.294 & 0.081 & 0.271 & IV \\
\hline $4(08)$ & 20.81 & 8.45 & 8 & 0.052 & 0 & 0.039 & 0.047 & III \\
\hline $5(08)$ & 25.41 & 7.24 & 8.27 & 0.020 & 0.023 & 0.009 & 0 & III \\
\hline $7(08)$ & 25.06 & 6.81 & 8.5 & 0.150 & 0.068 & 0.007 & 0 & III \\
\hline $8(08)$ & 25.79 & 5.48 & 8.72 & 0.153 & 0.045 & 0.006 & 0 & III \\
\hline $9(08)$ & 18.97 & 8.75 & 8.1 & 0 & 0 & 0 & 0 & I \\
\hline $10(08)$ & 19.75 & 8.83 & 8.35 & 0.147 & 0.045 & 0.002 & 0 & II \\
\hline $11(08)$ & 18.94 & 7.97 & 8.35 & 0.330 & 0.023 & 0.006 & 0 & II \\
\hline $13(09)$ & 14.28 & 9.04 & 6 & 1.94 & 0 & 0.0015 & 0.078 & III-IV \\
\hline $14(09)$ & 19.47 & 8.81 & 7.2 & 2.23 & 0.023 & 0.0018 & 0 & IV \\
\hline $15(09)$ & 15.91 & 8.94 & 6.5 & 1.77 & 0.113 & 0.0024 & 0 & III-IV \\
\hline $16(09)$ & 17.99 & 8.43 & 6.9 & 2.71 & 0.045 & 0.0043 & 0 & IV \\
\hline $17(09)$ & 8.65 & 12.18 & 6.3 & 2.53 & 0.045 & 0.0034 & 0 & IV \\
\hline $18(09)$ & 14.88 & 10.78 & 6 & 2.30 & 0.113 & 0.0055 & 0 & IV \\
\hline
\end{tabular}

As a result of this study, one genus and eleven species (Metacnephia sp., Metacnephia subalpina, Simulium (Eusimulium) angustipes, Simulium (Nevermannia) costatum, Simulium (Simulium) argenteostriatum, Simulium (Simulium) bezzii, Simulium (Simulium) ornatum, Simulium (Simulium) trifasciatum, Simulium (Simulium) variegatum, Simulium (Wilhelmia) balcanicum, Simulium (Wilhelmia) lineatum and Simulium (Wilhelmia) pseudequinum) were recorded from 16 collecting sites (Tab. 2a, b).

The most common species in the Yeşilırmak River were Simulium (S.) bezzii, Simulium (W.) balcanicum and Simulium (W.) pseudequinum. These three species have a wide-spread distribution in Palearctic Region and they were recorded in many regions in Turkey (Ertunç, 2009; Kalafat, 2008; Kazanc1, 2006; Şirin, 2001; Clergue-Gazeau and Kazanc1, 1992; Crosskey and Zwick, 2007; Kazancı and Ertunç, 2008a; Kazancı and Ertunç, 2008b; Kazancı and Ertunç, 2008c; Kazanc1 and Ertunç, 2010; Başören (Ertunç) and Kazanc1, 2011; Başören (Ertunç) and Kazanc1, 2012; Başören and Kazanc1, 2012; Başören and Kazanc1, 2013; Başören et al., 2013; Ertunç et al., 2008).

Simulium (S.) bezzii has the ability to survive in eutrophic waters and it can live in physically degraded habitats (Kazanc1, 2006; Kazancı and Ertunç, 2010; Lechthaler and Car, 2005). This species prefers mainly oligosaprobic and betamesosaprobic environments (Car et al., 1995). Simulium (S.) bezzii was collected from eight sites (site 5 (08), site 8 (08), site 9 (08), site 10 (08), site $11(08)$, site 13 (09), site 15 (09) and site $16(09))$. It is expected that this species is found in these sites. 
Table 2a: Simuliidae list of collecting sites.

\begin{tabular}{|c|c|c|c|c|c|c|c|c|}
\hline & $1(08)$ & $2(08)$ & $3(08)$ & $4(08)$ & $5(08)$ & $7(08)$ & $8(08)$ & $9(08)$ \\
\hline Metacnephia sp. & & & & & & & & \\
\hline Metacnephia subalpina & & & & & & & & \\
\hline S. (E.) angustipes & & & & & $*$ & & * & \\
\hline S. (N.) costatum & & & & & & & * & \\
\hline S. (S.) argenteostriatum & & & & & & & * & \\
\hline S. (S.) bezzii & & & & & * & & * & * \\
\hline S. (S.) ornatum & & & & & & & $*$ & \\
\hline S. (S.) trifasciatum & & & & & & & * & \\
\hline S. (S.) variegatum & & & & & & & & \\
\hline S. (W.) balcanicum & * & * & * & * & * & & * & \\
\hline S. (W.) lineatum & & & & & & * & & \\
\hline S. (W.) pseudequinum & $*$ & & * & * & $*$ & & * & \\
\hline
\end{tabular}

Simulium (W.) balcanicum and Simulium (W.) pseudequinum which are other common species, live in similar environmental conditions and do not prefer special habitats (Lautenschlager and Kiel, 2005; Feld et al., 2002). Simulium (W.) balcanicum and Simulium (W.) lineatum are resistant to temperature changes and they can tolerate increasing temperature (Kazanc1, 2006; Stangler and Halgos, 2007). Simulium (W.) balcanicum prefers small running waters and it survives in disturbed environments while Simulium (W.) lineatum prefers medium-sized and sand-bottom lowland rivers and it survives in hydromorphologically undisturbed sites (Rubtsov, 1990). Simulium (W.) pseudequinum can be found in many different freshwater habitats (Feld et al., 2002). These three species prefer mainly betamesosaprobic and alphamesosaprobic environments (Car et al., 1995). Simulium (W.) balcanicum and Simulium (W.) pseudequinum were collected from the same sites (site 1 (08), site 3 (08), site 4 (08), site 5 (08), site 8 (08) and site $10(08)$ ). In site $2(08)$, Simulium (W.) balcanicum was found alone. Simulium (W.) lineatum was collected from only site 7 (08). These sites are suitable for the survival of the three species. 
Table 2b: Simuliidae list of collecting sites.

\begin{tabular}{|l|c|c|c|c|c|c|c|c|}
\hline & $\begin{array}{c}10 \\
(08)\end{array}$ & $\begin{array}{c}11 \\
(08)\end{array}$ & $\begin{array}{c}13 \\
(09)\end{array}$ & $\begin{array}{c}14 \\
(09)\end{array}$ & $\begin{array}{c}15 \\
(09)\end{array}$ & $\begin{array}{c}16 \\
(09)\end{array}$ & $\begin{array}{c}17 \\
(09)\end{array}$ & $\begin{array}{c}18 \\
(09)\end{array}$ \\
\hline Metacnephia sp. & & & & & & & & $*$ \\
\hline Metacnephia subalpina & & & & & & & $*$ & \\
\hline S. (E.) angustipes & & & & & & & & \\
\hline S. (N.) costatum & & & & & & & & \\
\hline S. (S.) argenteostriatum & & & & & & & & \\
\hline S. (S.) bezzii & $*$ & $*$ & $*$ & & $*$ & $*$ & & \\
\hline S. (S.) ornatum & & & & & $*$ & $*$ & & \\
\hline S. (S.) trifasciatum & & & & $*$ & $*$ & $*$ & & \\
\hline S. (S.) variegatum & & & & & $*$ & & & \\
\hline S. (W.) balcanicum & $*$ & & & & & & & \\
\hline S. (W.) lineatum & & & & & & & & \\
\hline S. (W.) pseudequinum & $*$ & & & & & & & \\
\hline
\end{tabular}

Simulium (S.) ornatum has not specific habitat requirements and the distribution of this species is not dependent on water temperature, flow rate and substrate structure (Bernotiene, 2006). It can survive in both in polluted freshwaters and in clean waters (Lechthaler and Car, 2005; Ignjatovic Cupina et al., 2003). For this reason, Simulium (S.) ornatum is one of the most common species of Simuliidae family in Europe (Crosskey and Howard, 2004). This species prefers mainly alphamesosaprobic and betamesosaprobic environments, but it is also found in oligosaprobic environments (Car et al., 1995). Simulium (S.) ornatum was collected from site 8 (08), site 15 (09) and site 16 (09) and these sites are suitable for the survival of this species.

Simulium (S.) trifasciatum spreads almost all over Europe (Crosskey and Howard, 2004). It is mostly found in small and clean streams (Bass, 1998). The larvae prefer streams with low organic pollution (Bernotiene, 2006). This species is generally found in oligosaprobic and betamesosaprobic environments (Car et al., 1995). It was collected from site 8 (08), site 14 (09), site 15 (09) and site 16 (09). It is expected to find this species at these sites. 
Simulium (S.) variegatum is well adapted to high currents and it is found in upland streams (Kiel, 2001). Also, it was determined that this species can live in degraded sites (Lautenschlager and Kiel, 2005). This species prefers mainly oligosaprobic and betamesosaprobic environments, but it is also found in xenosaprobic and alphamesosaprobic environments (Car et al., 1995). It was collected only from site 15 (09), this site is suitable for the survival of this species.

Simulium (E.) angustipes is widely spread all over Europe (Crosskey and Howard, 2004). This species inhabits small, lowland streams which are rich in nutrients (Lechthaler and Car, 2005). It prefers mostly betamesosaprobic environments and is found in epirhithron and metarhithron of running waters (Car et al., 1995). Simulium (E.) angustipes was collected from site 5 (08) and site 8 (08). It is to be expected to find this species in these areas.

Simulium (N.) costatum can be found throughout Europe (Crosskey and Howard, 2004). This species prefers small springs and attaches onto plants (Rubtsov, 1990). Also, Simulium (N.) costatum is very resistant to low current velocity (Jensen, 1997). It is generally found in oligosaprobic and betamesosaprobic running waters (Car et al., 1995). This species was collected from only site $8(08)$ and this site is suitable for the survival of this species.

Simulium (S.) argenteostriatum lives in fast-flowing mountain streams (Lechthaler and Car, 2005). This species prefers mainly oligosaprobic environment but it can also be found in xenosaprobic environments (Car et al., 1995). It was collected only from site 8 (08) like Simulium (N.) costatum. The water quality of site 8 (08) was Class III. According to the results of this study, Simulium (S.) argenteostriatum can also inhabit moderately polluted sites.

The saprobic level of the Metacnephia species is unknown, but species of this genus are usually found in unregulated streams with high water flow (Malmqvist, 1999) and prefer oligosaprobic environments in Spain (Gallardo-Mayenco and Toja, 2002) and in Turkey (Kazanc1 and Ertunç, 2010). Metacnephia subalpina was collected only from site 17 (09) and Metacnephia sp. was collected only from site 18 (09). Water quality of these sites was Class IV due to the level of $\mathrm{PO}_{4}-\mathrm{P}$ concentration and the site' $\mathrm{pH}$ values. These variables were affected by snowmelt and rainstorms. Individuals may have drifted downstream to sampling sites.

The current velocity is very important for many passive filter feeding Simuliidae larvae (Bernotiene, 2006). The larvae and pupae of Simuliidae are affected by any change in river conditions and they could leave their habitat because of these changes (Rubtsov, 1990).

This study shows that the species composition may have been affected by various abiotic and biotic factors. Community structures of Simuliidae were negatively affected by dam impacts in particular.

\section{CONCLUSIONS}

According to the results of this study, environmental impacts and pollution were observed in Yeşilırmak River and tributaries. Dams and hydroelectric power plants on the river caused changes in temperature, dissolved oxygen concentrations and flow regime. Other effects of dam and hydroelectric power plants are habitat loss and sedimentation. Also, Yeşilırmak River and surrounding area have been threatened by agricultural pollution and domestic wastes. Due to all these activities, 16 collecting sites located on the Yeşilırmak River were characterized as mainly betamesosaprobic (Class III) and alphamesosaprobic (Class IV).

The community structures of Simuliidae and water qualities of their habitats were negatively affected in the Yeşilırmak River basin. If this continues, diversity of species of Simuliidae and other benthic macroinvertebrates will start to decline. Therefore, the long term physicochemical and biological monitoring of the water quality and controlling the pollution caused by agricultural and domestic wastes is crucially important. 


\section{ACKNOWLEDGEMENTS}

This research has been supported by Hacettepe University Research Foundation (BAP) (Project leader Mr. Nilgün Kazanc1, Project title "Constitution of biotic index for long-term biomonitoring of water quality for Yeşilırmak River by using benthic macroinvertebrates” and Project 0701601005).

\section{REFERENCES}

1. Adler P. H. and Şirin Ü., 2014 - Cytotaxonomy of the Prosimulium (Diptera: Simuliidae) of Western Asia, Zoological Journal of the Linnean Society, 171, 753-768.

2. Bass J. A. B., 1998 - Last-Instar Larvae and Pupae of the Simuliidae of Britain and Ireland. A key with brief ecological notes, Freshwater Biological Association, 55, 104.

3. Başören (Ertunç) Ö. and Kazancı N., 2011 - The distributional of Simuliidae (Insecta, Diptera) species in some streams of Yedigöller National Park (Bolu, Turkey), Review of Hydrobiology, 4, 2, 73-86.

4. Başören (Ertunç) Ö. and Kazancı N., 2012 - Clustering of Simuliidae (Insecta, Diptera) species and sampling sites according to their similarities by using UPGMA method, Review of Hydrobiology, 5, 1, 19-34.

5. Başören Ö. and Kazancı N., 2012 - Contribution to the knowledge of Simuliidae (Diptera, Insecta) fauna of Turkey: Eastern Black Sea Region, Review of Hydrobiology, 5, 2, 121-130.

6. Başören Ö. and Kazancı N., 2013 - Additional species records of Simuliidae (Insecta, Diptera) fauna of Eastern Black Sea Region (Turkey), Review of Hydrobiology, 6, 1, 81-89.

7. Başören Ö., Kazancı N. and Girgin S., 2013 - The distribution of Simuliidae (Insecta, Diptera) species in Ankara Stream (Turkey), Review of Hydrobiology, 6, 2, 157-167.

8. Bernotiene R., 2006 - On the distribution of black fly larvae in small lowland rivers in Lithuania, Acta Entomologica Serbica, 11, 115-125.

9. $\quad$ Car M., Mohrig W., Moog O., Oosterbroek P., Reusch H., Wagner R. and Zwick P., 1995 Diptera (except Chironomidae) (authors depending on family), in Moog O. (ed.), Fauna Aquatica Austriaca, Lieferungen 1995, 2002. Wasserwirtschaftskataster, Bundesministerium für Land-und Forstwirtschaft, Umwelt und Wasserwirtschaft, Wien. www.freshwaterecology.info

10. Clergue-Gazeau M. and Kazancı N., 1992 - Türkiye Simuliidae (Insecta: Diptera) Faunası II. Çeşitli akarsu sistemlerinden toplanmış türlere ekolojik bir yaklaşım, Hacettepe Fen ve Mühendislik Bilimleri Dergisi, 13, 17-32. (in Turkish)

11. Crosskey R. W. and Zwick H., 2007 - New Faunal Records with Taxonomic Annotations for the Blackflies of Turkey (Diptera: Simuliidae), Aquatic Insects, 29, 1, 21-48.

12. Crosskey R. W. and Howard T. M. A., 2004 - A revised taxonomic and geographical inventory of world blackflies (Diptera: Simuliidae). NHM, London, download: Updated edition 27/05/2004, http://www.nhm.ac.uk/research-curation/projects/blackflies/.

13. Curtean-Bănăduc A., 2012 - Orăştie (Mureş Watershed, Romania) ecological status, based on the structure of benthic macroinvertebrate communities, Acta Oecologica Carpatica, V, 111-124.

14. Ertunç Ö., 2009 - Türkiye'nin Batısındaki Bazı Akarsuların Simuliidae (Insecta, Diptera) Faunası Üzerine Bir Araştırma, Yüksek Lisans Tezi, Hacettepe Üniversitesi, Fen Bilimleri Enstitüsü, Ankara, 113. (in Turkish)

15. Ertunç Ö., Türkmen G. and Kazancı N., 2008 - Yedigöller Milli Parkı (Bolu, Türkiye) Simuliidae (Insecta, Diptera) Faunası üzerine bir araştırma, Review of Hydrobiology, 1, 2, 81-92. (in Turkish)

16. Feld C. K., Kiel E. and Lautenschlager M., 2002 - The indication of morphological degradation of streams and rivers using Simuliida, Limnologica, 32, 273-288.

17. Gallardo-Mayenco A. and Toja J., 2002 - Spatio-temporal Distribution of Simuliids (Diptera) and Associated Environmental Factors in two Mediterranean Basins of Southern Spain, Limnetica, 21, 1-2, 47-57. 
18. Ignjatović Ćupina A., Petrić D., Zgomba M., Konjević A. and Grabovac S., 2003 - Distribution of some blackfly species (Diptera, Simuliidae) in the region of Novi Sad, British Simuliid Group Bulletin, 2, 6-7.

19. Jensen F., 1997 - Diptera Simuliidae, Blackflies, in Nilsson A. N. (ed.), Aquatic Insects of North Europe, 2, 209-241.

20. Kalafat A., 2008 - Afyon ve çevresi Simuliidae (Diptera) faunası üzerine araştırmalar, Yüksek Lisans Tezi, Osmangazi Üniversitesi, Eskişehir, 96. (in Turkish)

21. Kazancı N., 2006 - Ordination of Simuliidae and climate change impact, Acta Entomologica Serbica, Supplement, 69-76.

22. Kazancı N., 2009 - Records of Plecoptera (Insecta) species and affects of episodic acidification on physico-chemical properties of their habitats in the Eastern Black Sea Region and Yeşilırmak River basin (Turkey), Review of Hydrobiology, 2, 2, 197-206.

23. Kazanci N. and Clergue-Gazeau M., 1990 - Simuliidae de Turquie, Prèmier données faunistiques et biogéographiques (Diptera, Simuliidae), Annales de Limnologie, 26, 45-50.

24. Kazancı N. and Ertunç Ö., 2008a - Türkiye Simuliidae (Insecta, Diptera) Faunası üzerine araştırmalar, Review of Hydrobiology, 1, 27-36. (in Turkish)

25. Kazancı N. and Ertunç Ö., 2008b - Bazı Simuliidae (Insecta, Diptera) türlerinin habitat özellikleri, Ege Üniversitesi Su Ürünleri Dergisi, 25, 4, 319-323. (in Turkish)

26. Kazancı N. and Ertunç Ö., 2008c - Checklist of the Simuliidae (Insecta, Diptera) of Turkey, Review of Hydrobiology, 1, 2, 129-144.

27. Kazancı N. and Ertunç Ö., 2010 - Use of Simuliidae (Insecta: Diptera) species as indicators of aquatic habitat quality of Yeşilırmak River basin (Turkey), Review of Hydrobiology, 3, 1, 27-36.

28. Kiel N., 2001 - Behavioural Response of Blackfly Larvae (Simuliidae, Diptera) to Different Current Velocities, Limnologica, 31, 3, 179-83.

29. Klee O., 1991 - Angewandte Hydrobiologie, Georg Thieme Verlag Stuttgart, New York, 272.

30. Lautenschlager M. and Kiel E., 2005 -Assessing morphological degradation in running waters using blackfly communities (Diptera, Simuliidae): Can habitat quality be predicted from land use? Limnologica, 35, 262-273.

31. Lechthaler W. and Car M., 2005 - Simuliidae - Key to Larvae and Pupae from Central and Western Europe. CD-Rom - Edition, Vienna, http://www.eutaxa.com ISBN: 3-9501839-3-0.

32. Malmqvist B., 1999 - Life History of Metacnephia lyra, a Blackfly Highly Characteristic of Large Swedish River Rapids at the Time of Maximum Discharge (Diptera: Simuliidae), Aquatic Insects, 21, 2, 89-98.

33. Ministry of Forestry and Water Management, 2012 - Regulations of Surface Water Quality Management, 28483, 26.

34. Rubtsov I. A., 1990 - Blackflies (Simuliidae), Fauna of the USSR Diptera, 6, 6, Brill E. J. Publishing Company, 1024.

35. Stangler A. and Halgos J., 2007 - The structure of blackfly communities (Diptera, Simuliidae) in the longitudinal profile of some streams in the Male Karpaty Mounts and the Borskanizina low land, Acta Zoologica Universitatis Comenianae, 47, 2, 237-245.

36. Şirin Ü., 2001 - Yukarı Sakarya Nehir Sistemi Simuliidae Faunasının Tespiti, Doktora Tezi, Osmangazi Üniversitesi, Eskişehir, 134. (in Turkish)

37. Şirin Ü., Çalışkan H. and Şahin Y., 2015 - Black flies (Diptera: Simuliidae) of Turkish Thrace, with a new record for Turkey, Biodiversity Data Journal, 3:e4834, doi: 10.3897/BDJ.3.e4834.

38. Wellington B. I. and Driscoll C. T., 2004 - The episodic acidification of a stream with elevated concentrations of dissolved organic carbon, Hydrological Processes, 18, 2663-2680.

39. Zhang Y., Malmqvist B. and Englund G., 1998 - Ecological processes affecting community structure of blackfly larvae in regulated and unregulated rivers: A regional study, Journal of Applied Ecology, 35, 673-686. 